\title{
ArcheoSciences
}

Revue d'archéométrie

\section{Maya Metallurgical Technology in Late Postclassic- Spanish Colonial Times: The View from Lamanai, Belize}

Technologie métallurgique maya du postclassique tardif à l'époque de la colonisation espagnole : perspective de Lamanai, Bélize

Scott E. Simmons and Aaron N. Shugar

\section{OpenEdition}

\section{Journals}

\section{Electronic version}

URL: https://journals.openedition.org/archeosciences/4071

DOI: 10.4000/archeosciences.4071

ISBN: 978-2-7535-2755-3

ISSN: $2104-3728$

\section{Publisher}

Presses universitaires de Rennes

\section{Printed version}

Date of publication: 17 April 2013

Number of pages: $105-123$

ISBN: 978-2-7535-2757-7

ISSN: $1960-1360$

Electronic reference

Scott E. Simmons and Aaron N. Shugar, "Maya Metallurgical Technology in Late Postclassic-Spanish Colonial Times: The View from Lamanai, Belize", ArcheoSciences [Online], 37 | 2013, Online since 17 April 2015, connection on 28 January 2022. URL: http://journals.openedition.org/archeosciences/ 4071 ; DOI: https://doi.org/10.4000/archeosciences.4071 


\title{
Maya Metallurgical Technology in Late Postclassic-Spanish Colonial Times: The View from Lamanai, Belize
}

\author{
Technologie métallurgique maya du postclassique tardif \\ à l'époque de la colonisation espagnole: \\ perspective de Lamanai, Bélize
}

\author{
Scott E. Simmons* et Aaron N. Shugar ${ }^{* *}$
}

\begin{abstract}
Recent archaeometallurgical studies at the ancient Maya site of Lamanai, Belize have begun to reveal the nature of copper metallurgy in the centuries just prior to and during Spanish contact in the Southern Maya Lowland Area. More copper artifacts have been recovered from controlled archaeological excavations at Lamanai than at any other site in the Southern Maya Lowland area. A total of 187 copper objects dating to the 12th through 16th centuries AD have been recovered; among these objects are ingots or pigs, blanks, prills and a substantial number of mis-cast objects, many of which are bells. The archaeological contexts in which copper bells, axes, needles, fish hooks, rings, and clothing ornaments have been recovered will be summarised. Forming technologies used in the creation of Maya copper artifacts as well as their chemical compositions were studied using scanning electron microscopy and optical light microscopy. The results of chemical compositional and microstructural analyses will be presented and discussed in the contexts of larger social and economic spheres that were part of the Maya world just before and during Spanish contact in Belize.
\end{abstract}

Résumé: De récentes études concernant l'archéométallurgie sur l'ancien site maya de Lamanai, Belize ont permis de révéler la nature de la métallurgie du cuivre des siècles avant et pendant la période de contact espagnol dans la zone sud des basses terres mayas. Le nombre d'artéfacts en cuivre découverts lors de fouilles archéologiques contrôlées à Lamanai dépasse tout ce qui a été mis au jour dans les autres sites localisés dans la même région. Un total de 187 objets en cuivre datant des XII jusqu'au XVI siècle de notre ère ont été découverts. Parmi ces objets on retrouve entre autres des lingots ou barres en cuivre, des douilles, sphérules ainsi qu'un certain nombre d'objets mal moulés, lesquels sont principalement des cloches. Les contextes archéologiques dans lesquels les cloches en cuivre, haches, aiguilles, hameçons, anneaux ainsi que les ornements pour vêtements ont été découverts seront brièvement expliqués. Les moyens technologiques utilisés dans la création d'artéfacts mayas en cuivre tout comme leurs compositions chimiques ont été étudiés par microscope électronique à balayage ainsi que microscope optique. Les résultats des composants chimiques et analyses microstructurales seront présentés et expliqués dans les contextes plus larges des sphères sociales et économiques qui faisaient partie intégrantes du monde maya avant et pendant les contacts espagnols au Belize.

Keywords: archaeometallurgy, Belize, copper, Postclassic, Spanish Colonial, technology.

Mots-clés : archéométallurgie, Belize, cuivre, Postclassic, Espagnol Coloniale, technologie.

* Department of Anthropology, University of North Carolina Wilmington, 601 South College Road Wilmington, North Carolina 28409, USA.

** Art Conservation Department, Buffalo State College, Rockwell Hall, 1300 Elmwood Avenue, Buffalo, New York 14222, USA. 


\section{INTRODUCTION}

Metallurgy began in Mesoamerica sometime between AD 600-650, roughly nine centuries prior to Spanish contact in the region (Hosler, 1986, 1994, 1995, 2001). The first copper objects were produced in West Mexico and metal objects began to appear in the Southern Maya Lowlands shortly after this time. Recent archaeological investigations in the Southern Lowlands have provided important insights into technological aspects of copper metallurgy in this region of Mesoamerica (Simmons and Shugar, 2013; Simmons et al., 2009). Key evidence for indigenous production of copper objects has recently come to light from Postclassic and Spanish Colonial Period contexts at the site Lamanai, a prominent Maya center located in northern Belize. Archaeological data, in combination with ethnohistorical information and the results of recent chemical compositional and microstructural analyses of excavated

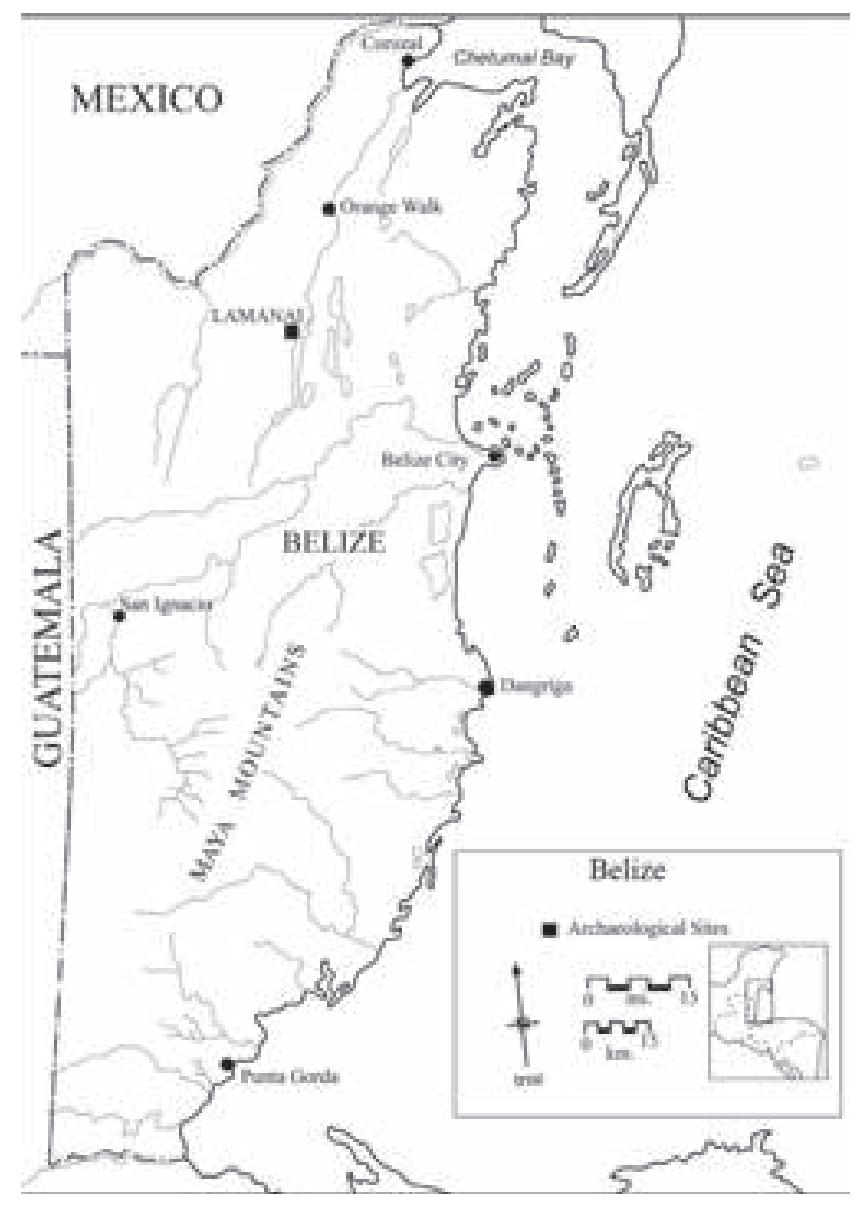

Figure 1: Location of Lamanai, Belize.

Figure 1: Situation géographique de Lamanai, Bélize. metal artifacts, are providing an understanding of the roles copper metallurgy played in the political economy of the Maya just prior to and during the Spanish Colonial Period as well as the technological nature of this specialized craft activity.

This paper summarizes the results of recent analytical research conducted on copper-base artifacts found at the site of Lamanai, which is located on the west bank of the New River Lagoon in the Orange Walk District of Belize (Figure 1). The research is part of the Maya Archaeometallurgy Project (MAP), which began at Lamanai in 1999 (Simmons, 1999). One of the principal goals of the project is to examine the organizational structure of ancient Maya metallurgy and the roles metal objects played in Postclassic and Spanish Colonial Period Maya society. Another goal of the MAP is to understand production technology, including the use of raw materials, creation of molds, casting and annealing techniques, and recycling behavior. This paper presents the results of recently conducted analyses that address this second goal of understanding metallurgical technologies used by the ancient Maya. Several of the copper artifact types and the technologies used to create them have not been reported on from the Maya area before. Others discussed here provide additional supporting evidence for the nature of Maya metallurgical technologies that have been discussed previously (Hosler, 1994; Hosler and McFarlane, 1996; Simmons et al., 2009).

\section{Copper at Lamanai, Belize - A Summary Overview}

One of the largest precolumbian sites in Belize, Lamanai was continuously occupied from roughly $1500 \mathrm{BC}$ through the Spanish and British Colonial eras (Pendergast, 1981, 1986, 1991, 1993). Its setting on a major transportation route, the New River system, facilitated Maya participation in broad inter- and intra-regional interaction spheres throughout its long history. Copper-base objects were one of the commodities that began flowing into the site in Early Postclassic times ( $c a$ AD 950-1200). In this paper we use the term "copper" for the sake of brevity since it is by far the dominant metallic element present, although many of the copper-base artifacts from Lamanai were intentionally alloyed with other metals, especially tin and arsenic. Sometime after the Middle Postclassic Period ( $c a$ AD 1200-1350) the residents of Lamanai began experimenting with the production of copper objects themselves. The evidence presently available suggests that the production of copper objects at Lamanai was taking place at least by Late 
Postclassic times ( $c a \mathrm{AD} 1350-1500)$ and continued into the Spanish Colonial Period (ca AD 1500-1700).

More copper and alloyed copper artifacts have been recovered archaeologically at Lamanai than from any other site in the Southern Maya Lowlands. In the entire Maya area, only Chichén Itzá and Mayapán, both in the Northern Lowlands, have yielded more copper and copper-tin bronze artifacts (Lothrop, 1952; Paris, 2008). Almost all of the metal artifacts from Lamanai are copper-base; 187 of these have been recovered archaeologically at the site to date (Simmons et al., 2009). A total of 36 copper objects were analysed for this particular study using a variety of analytical methods discussed below. A small number of other metallic artifacts, including sheet gold and lead have been recovered during archaeological investigations at Lamanai, but it is the copper artifacts that are the focus of the analyses and interpretations that are summarised here.

Dating of copper artifacts at Lamanai rests mainly on their co-occurrence with temporally diagnostic ceramic forms, but in a great many instances these dates have been corroborated by associated radiocarbon samples (Simmons et al., 2009: 64). The copper objects that have been recovered thus far at Lamanai fall into three broad chronological periods that are associated with distinct ceramic phases: the Early Postclassic Buk ceramic phase (ca AD 950-1200), the Middle Postclassic Cib ceramic phase ( $c a$ AD 12001350) and the Late and Terminal Postclassic (AD 13501544) and Spanish Colonial Period Yglesias ceramic phase (ca AD 1544-1700) (Simmons et al., 2009: 58). Continuing studies of ceramic artifacts (Aimers, 2007, 2013; Howie, 2007) are enabling us to further refine the ceramic chronology of Lamanai. But at present it is not possible to confidently differentiate Late and Terminal Postclassic Period deposits from those dating to Spanish Colonial times on the basis of Yglesias phase ceramics alone since Yglesias vessels were produced by the Maya at Lamanai prior to as well as following Spanish contact (Graham, 2004). Copper artifacts have been recovered in association with European artifacts, including Spanish olive jar and majolica sherds as well as glass beads (Pendergast, 1985; Simmons, 2004, 2005a, 2005b). Yet the presence of Maya metals alongside objects of European manufacture does not necessarily indicate that copper objects were being produced at Lamanai only after Spanish contact. In fact, several lines of evidence indicate that copper metalworking in the Southern Lowlands was an indigenous enterprise that pre-dates Spanish contact by possibly half a century or more and continued into the colonial period (see below discussion).

This study elaborates on chemical compositional and metallographic analyses conducted roughly two decades ago on a sample of the Lamanai copper assemblage recovered during Royal Ontario Museum (ROM) investigations at Lamanai in the 1970's and 1980's (Hosler, 1994; Pendergast, 1981, 1991, 1993; Williams, 1990). A total of 45 metal objects were analysed during this earlier study, which focused on metal artifacts from Early and Middle Postclassic as well as Historic Period archaeological contexts (Hosler, 1994: 209; Williams, 1990: 17). In contrast, ongoing analyses being conducted by Shugar $(2005,2008)$ are concentrating on metal artifacts recovered in the Spanish Church Zone at Lamanai, all of which are believed to date to the period just prior to and during Spanish contact in the 16th century. In this study we report on previously unknown types of copper artifacts found in the past decade during MAP investigations in the Spanish Church Zone. We also summarise the results of chemical compositional and microstructural analyses that have revealed new information on Maya metallurgical technologies using data from these recently recovered metal objects.

Although it is the currently conducted research that is the principal focus of this paper the results of earlier research will be referred to here in conjunction with this recent work (Shugar, 2005, 2008). Taken together, these studies comprise the most comprehensive analyses of metal objects from the Maya area that have been completed to date, and the results of these analyses have allowed us to gain a better understanding of Maya metallurgical technologies in the Southern Lowland area.

\section{Methods of Analysis}

Current analyses of Maya metals from Lamanai are focusing on two main aspects of metal production. The first involves the identification of forming technology, the process in which the metal artifact was made (casting, hammering, sharpening, and surface decoration). Metallographic examinations are being accomplished using optical light microscopy, wherein small pieces of copper artifacts are removed for sampling, mounted in epoxy resin, and ground and polished to a mirror-like finish. Samples are then viewed under variable $(50 \mathrm{x}-1000 \mathrm{x})$ power magnification and the revealing microstructure is indicative of the manufacturing technology that formed the object. All samples discussed here have been investigated using microscopy and were etched using alcoholic ferric chloride to enhance their metallurgical structure (Shugar, 2005, 2008).

The second method of investigation involves identifying the chemical composition of the sample of Lamanai's metal artifacts. Traditionally, an object's chemical composition 
can guide a researcher towards the original raw materials used for its production. This is an extremely important consideration when investigating an artifact, since one can not only determine potential trade patterns that existed for metal objects but also the compositions of a collection of artifacts can be compared to determine if their chemistry links them to a single manufacturing center. Scanning electron microscopy (SEM-EDS) is being used to reveal the chemical compositions of copper objects at Lamanai. Both optical light microscopy and SEM-EDS analysis were performed on mounted, polished sections which revealed the un-corroded internal metal. While the results of these studies are summarised here, more detailed discussions of both chemical compositional and metallographic analyses can be found elsewhere (Shugar, 2005, 2008). Additional analyses are being undertaken using inductively coupled plasma spectroscopy (ICP) and handheld X-ray Fluorescence (to assess the viability of this portable instrument's value for field analysis).

\section{Copper at Lamanai in Early and Middle Postclassic Times (CA AD 950-1350)}

A comparatively small number of copper artifacts have been recovered in association with Early and Middle Postclassic archaeological contexts at Lamanai (Table 1). All but two of the 27 copper objects recovered from Early Postclassic Buk and Middle Postclassic Cib ceramic phase deposits come from two structures, N10-2 and N10-4. Copper rings, bells, and elaborate clothing ornaments described by Hosler (1994: 208) as ritual or status display

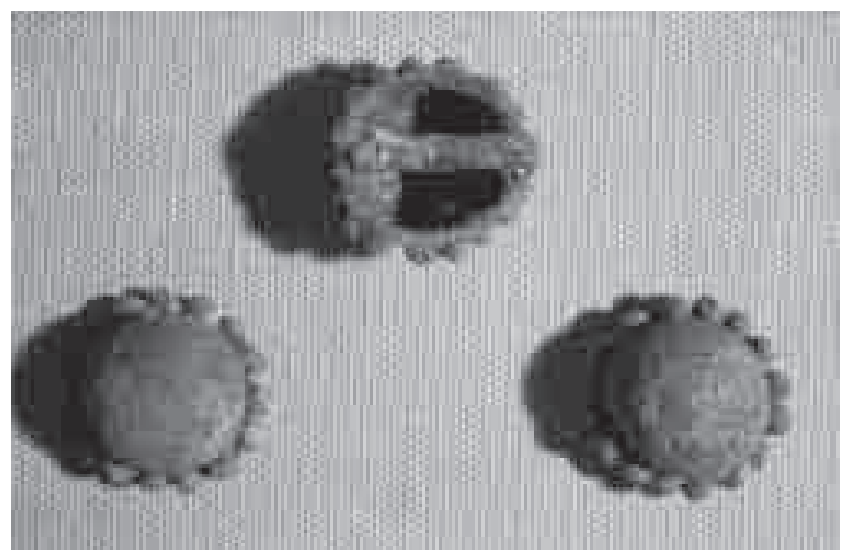

Figure 2: (See colour plate) Three of the six domed copper clothing ornaments (LA 90-8a-f) recovered with elite Burial N10-4/28. Each button-like object measures approximately $1.8 \mathrm{~cm}$ in diameter. These artifacts are identical to those made of gold found in Tomb 7 at Monte Albán, Oaxaca, Mexico. Early Postclassic Period. Figure 2: (Voir planche couleur) Trois des six ornements vestimentaires en cuivre (LA 90-8a-f) retrouvés avec la tombe d'élite N104/28. Chacun de ces objets en forme de bouton fait environ $1,8 \mathrm{~cm}$ de diamètre. Ils sont identiques à ceux en or trouvés dans la Tombe 7 à Monte Albán, Oaxaca, Mexique. Postclassique ancien.

Photo Courtesy of David Pendergast.

Photographies publiées avec l'autorisation de David Pendergast.

objects, were found in six of the 97 burials excavated from these two structures. Most of these objects $(n=17)$ were found associated with earlier Buk Phase ceramic artifacts while two bells, two bell-headed pins and six dome-shaped button-like ornaments (Figure 2) were found with later Cib Phase ceramic vessels. Investigations at Strs. N10-2

\begin{tabular}{|c|c|c|c|c|c|}
\hline Object Type $^{*}$ & \multicolumn{5}{|c|}{ Total Number by Ceramic Phase } \\
\hline & Buk & Cib & Yglesias & Unknown & TOTAL \\
\hline Status display/ritual & 17 & 9 & 63 & 14 & 103 \\
\hline Utilitarian & 0 & 0 & 42 & 2 & 44 \\
\hline $\begin{array}{c}\text { Manufacturing material/ } \\
\text { debris }\end{array}$ & 1 & 0 & 38 & 1 & 40 \\
\hline TOTAL & 18 & 9 & 143 & 17 & 187 \\
\hline
\end{tabular}

Table 1: Copper Artifacts from Lamanai by Functional Category.

Tableau 1: Objets en cuivre de Lamanai par catégorie fonctionnelle.

*Status display and ritual items: tweezers, rings, bells, clothing ornaments, bell-headed pins. Utilitarian objects: axe/chisel, needles, pins, pin tips, pin heads and fish hooks. Manufacturing materials/debris: Ingots, sheet pieces, prills, axe blanks, axe fragments, casting reserviors, mis-cast bells \& bell fragments.

*Marque de statuts et objets rituels: pinces, bagues, cloches, ornements vestimentaires, épingles à tête campaniforme. Objets utilitaires: hachelburin, aiguilles, épingles, pointes d'épingles, têtes d'épingles et hameçons. Matériaux/débris de manufacture: lingots, morceaux de feuille, prills, blanks de hache, fragments de hache, réservoirs de moulage, cloches mis-cast et fragments de cloche. 


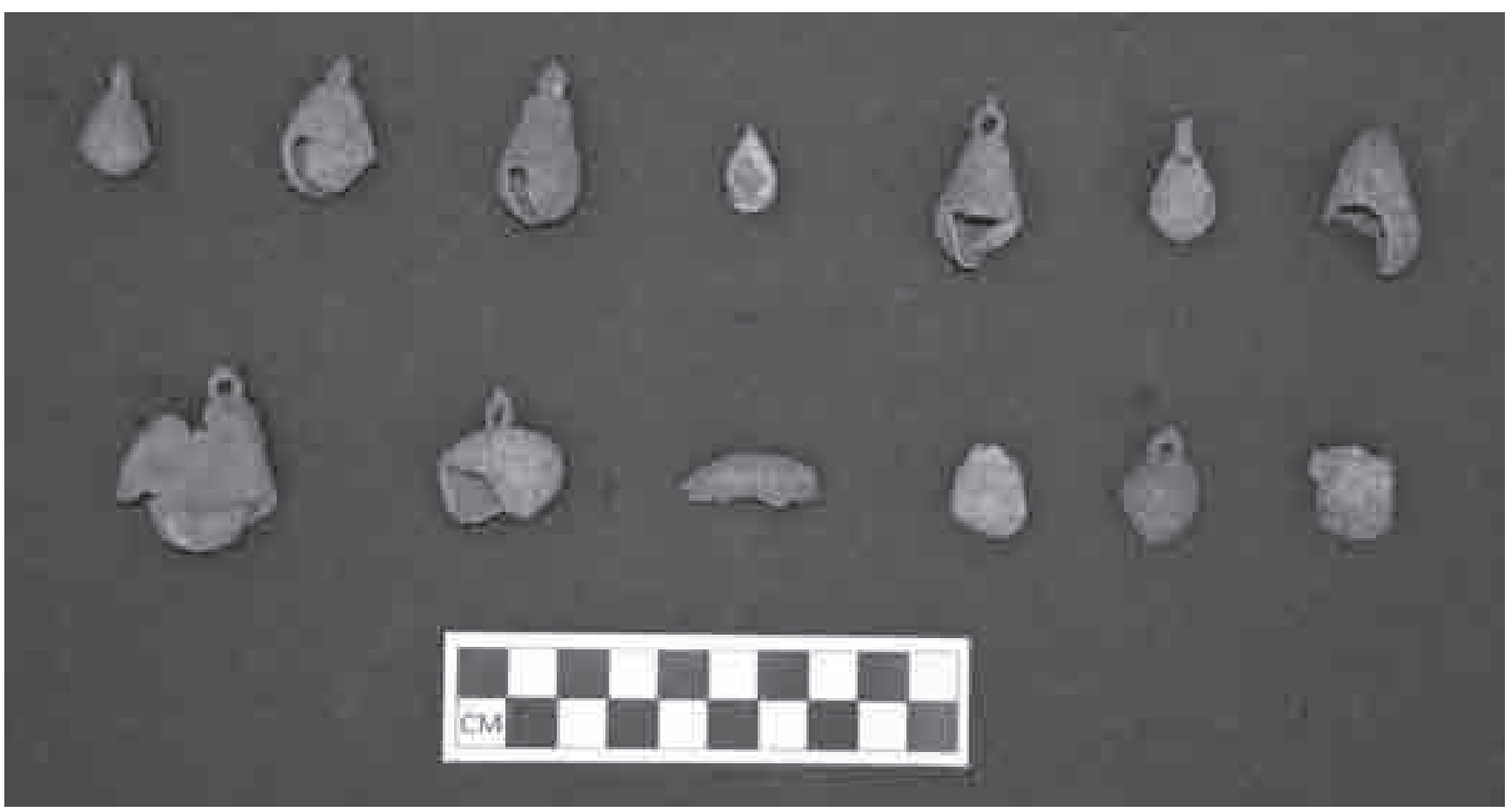

Figure 3: Cast bell varieties from Lamanai, Belize.

Figure 3 : Diverses cloches fondues de Lamanai, Bélize.

Note mis-cast bells and bell fragments in upper right, bottom center and bottom right of image. All of these bells were recovered from Late Postclassic-Spanish Colonial Period contexts at Lamanai.

Remarquez les cloches mis-cast et les fragments de cloches en haut à droite ainsi qu'en bas au centre et à droite. Toutes ces cloches ont été retrouvées dans des contextes datant du postclassique tardif et de la période de la colonisation espagnole à Lamanai.

and N10-4 showed that along with these copper objects Lamanai's Postclassic elites were buried with ceramic vessels, pyrite mirrors, beads of various materials, stingray spines, shark teeth, and a variety of perishable items, some of which were covered in sheet gold.

Clearly, the individuals interred in Structures N10-2 and N10-4 enjoyed elevated positions of social standing in the community given their burial contexts and the range of exotic, symbolically charged materials they had the ability to acquire (Simmons, n.d.). It is worth noting that although ROM investigations were fairly comprehensive in this area of the site none of the utilitarian copper tools recovered in later deposits, including axes, needles, and fishhooks, have been found in Early and Middle Postclassic Period contexts. In addition, no copper production materials dating to the first few centuries of the Postclassic Period have thus far been identified.

Instead, the results of earlier chemical compositional analyses indicate that all of the copper used to produce the bells, clothing ornaments and rings recovered in Early and Middle
Postclassic deposits originated from West Mexican ore fields and unidentified sources in southeastern Mesoamerica (Hosler, 1994: 208-213; Hosler and MacFarlane, 1996: 1822). The copper artifacts from this time consist of lostwax cast objects of complex design that are made almost exclusively of copper (see Long, 1964 for a detailed discussion of the lost-wax casting process). The filigree rings, bells and elaborate dome-shaped and S-scroll ornaments found at these structures adorned Lamanai's elites during their lives, perhaps as they walked through those very buildings, and accompanied them to their graves there (Simmons et al., 2009: Figure 4).

\section{Copper at lamanai in Late and Terminal Postclassic-Spanish Colonial Times (CA AD 1350-1700)}

Near the end of the Postclassic Period there is a shift in both the origins and forms of metal objects the Maya were 
using at Lamanai. By the late 15 th century fewer metal objects were being imported into Lamanai from outside the Maya area. The results of chemical compositional analyses indicate that probably sometime in the final centuries before Spanish contact Maya metalworkers were producing copper objects at Lamanai using recycled metal (Hosler, 1994: 214; Shugar, 2005, 2008). Stock metal derived from copper objects melted down at the site was used to create many of the bells, needles, fishhooks, axes and other mostly utilitarian objects that have been recovered in Terminal Postclassic and Spanish Colonial Period deposits. Plain walled bells dominate the copper assemblage during this time (Figure 3). As mentioned briefly above, recent archaeological investigations at Lamanai have been conducted in the Spanish Church Zone, an area of the site where two Spanish mission churches were constructed in the 16th and 17th Centuries (Pendergast, 1981, 1991, 1993; Simmons, 2004, 2005a, 2006; Simmons and Howard, 2003). Located approximately 925 meters south of Structures N10-2 and N10-4, the first of two churches was probably constructed sometime following the earliest recorded Spanish entrada (armed incursion) in AD 1544 (Pendergast, 1991). A second, much more substantial church was constructed in the first half of the 17th century near the first church, indicating the importance the Spanish placed on maintaining Lamanai as one of its missions in Belize. It is in this area of the site where the majority of copper artifacts from Lamanai have been recovered (Simmons et al., 2009).

A number of mis-cast metal objects, most of which are bells, have been recovered from Terminal Postclassic-Spanish Colonial Period deposits during MAP excavations in the Spanish church zone at Lamanai (Simmons, 2004, 2005a, 2006; Simmons and Howard, 2003). Although bells were traded widely throughout Mesoamerica at the time of Spanish contact (Hosler, 1994; Smith and Berdan, 2003) mis-cast bells, fragments of other casting failures and small pieces of sheet copper are unlikely to have been trade items, thus their presence provides compelling evidence for on-site metallurgy at Lamanai. These "failed" artifacts also reveal that Maya metalsmiths encountered problems during casting of certain objects, such as bells. These problems may have been the result of inadequate knowledge of, and training in, production techniques, and in the case of the bells this could have included improper construction of lost-wax molds (see Long, 1964).

\section{Results of Recent Metallurgical Analyses}

For this study the results of investigations of manufacturing technology and artifact chemistry are presented by material type and object form. The microstructures and

\begin{tabular}{|c|c|c|c|c|c|c|c|}
\hline Artifact No. & Reservoirs & $\mathrm{Cu}$ & $\mathrm{Sn}$ & As & $\mathrm{Fe}$ & $\mathrm{Ag}$ & $\mathrm{Ni}$ \\
\hline LA $2790-4$ & large reservoir & 97,7 & 1,1 & 0,9 & 0,2 & 0,3 & nd \\
\hline LA 2790-1 & small reservoir & 99,3 & 0,3 & nd & 0,2 & nd & nd \\
\hline LA 1149-1 & blank & 97,1 & 0,8 & 1 & 0,4 & 0,4 & 0,3 \\
\hline LA 2790-5 & Blade section long axe & 96 & 1,5 & 1,4 & 0,3 & 0,6 & nd \\
\hline LA 2790-7 & Back section short axe & 98,3 & 0,3 & 0,8 & 0,3 & 0,4 & nd \\
\hline LA 2791-1 & Axe fragment & 98,3 & nd & 0,9 & 0,3 & 0,5 & nd \\
\hline LA 1153-1 & Axe fragment & 97,2 & 1,2 & 1 & 0,3 & 0,3 & nd \\
\hline LA 1149-1 & blank & 97,1 & 0,8 & 1 & 0,4 & 0,4 & 0,3 \\
\hline LA $2790-5$ & Blade section long axe & 96 & 1,5 & 1,4 & 0,3 & 0,6 & nd \\
\hline LA 2790-7 & Back section short axe & 98,3 & 0,3 & 0,8 & 0,3 & 0,4 & nd \\
\hline LA 2791-1 & Axe fragment & 98,3 & nd & 0,9 & 0,3 & 0,5 & nd \\
\hline LA 1153-1 & Axe fragment & 97,2 & 1,2 & 1 & 0,3 & 0,3 & nd \\
\hline LA $1580-18$ & needle fragment & 98,5 & 0,4 & 0,5 & 0,3 & 0,6 & nd \\
\hline LA 1581-25 & needle & 98,2 & 0,3 & 0,6 & 0,2 & 0,4 & nd \\
\hline LA $1575-2$ & fish hook & 97 & 0,6 & 1,8 & 0,4 & 0,3 & nd \\
\hline
\end{tabular}

Table 2: Compiled SEM-EDS compositional data.

Tableau 2 : Liste de données compositionnelles SEM-EDS. 
chemistries of the artifacts analysed will be summarised by way of their respective categories of bells, needles, axes, sheet metal, reservoirs, blanks, and prills. We begin with a discussion of the recently discovered copper production materials found during MAP investigations in the Spanish Church Zone; these include casting reservoirs, prills and a large copper blank. We then continue by presenting the results of recent analyses of a sample of finished copper objects recovered in this area of the site. These include bells, axes, and needles. A summary compilation of SEM-EDS data for all the artifacts discussed here is presented in Table 2. Specific artifact data and a discussion of the relevance of the artifact compositions follow below.

\section{Production Materials}

Casting Reservoirs. Two artifacts, LA 2790/1 and LA 2790/4, were initially interpreted as ingots based on the characteristics of previously recovered artifacts of similar size and shape found at Lamanai (see Hosler, 1994: Figure 7.9). It was assumed that these objects were produced as ingots for transport to re-melt and cast new objects. Upon closer inspection these objects clearly match what could be termed casting or pouring reservoirs. These reservoirs are essentially the funnel-like portions of lost-wax cast molds into which molten metal was poured. After the metal fills the mold the reservoir serves as a receptacle for excess metal (Figure 4). Once the metal has cooled both the reservoir and the down sprue (the tube connecting the reservoir to the cast object) are removed and may later be recycled by remelting. If these objects are indeed casting reservoirs, as it appears they are, then they would be the first and only ones to be reported in the Maya area thus far.

Both artifacts have extensive copper oxide inclusions which under cross polarizing light appear bright red. This extensive copper oxide environment is expected in an oxygen-rich environment, as would be the case in an open casting reservoir. The grain formation is large and there are few annealing twins near the edges. These annealing twins are most likely due to the sample being hammered or struck to separate it from the down sprue. There is no evidence for cold working in either artifact. Reservoir LA 2790/4 has some inclusions at grain boundaries that represent copper sulfides.

Both reservoirs have varied chemical compositions (Table 3). The material observed in LA 2790/1 is a natural copper alloy with trace amounts of Sn. The limited inclusions in the metal are Sn rich. The material in LA 2790/4 is more complex in composition, more closely resembling the composition of recycled metals described by Holser

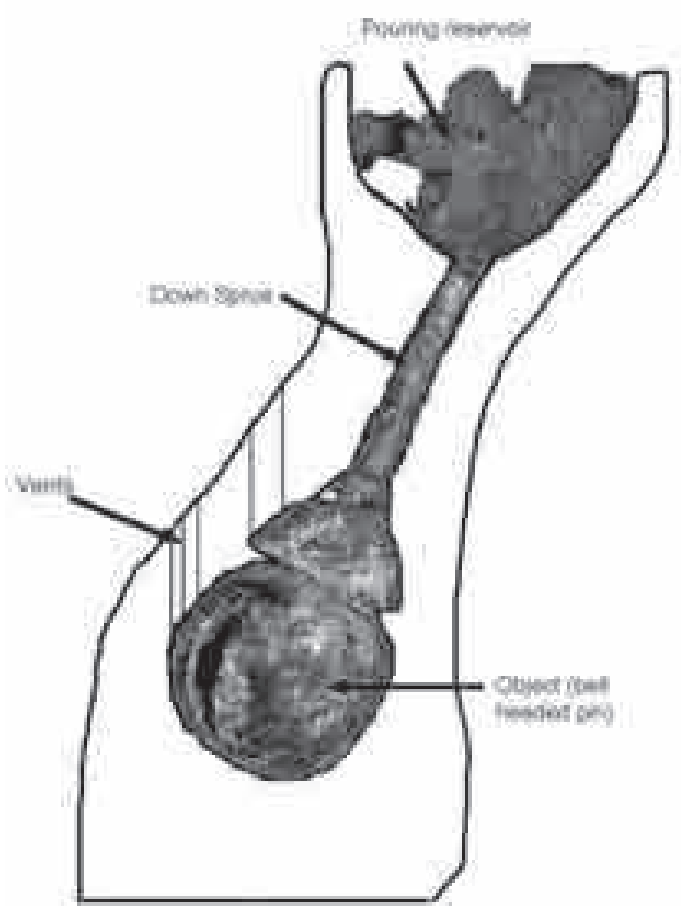

Figure 4: Schematic of a lost wax mold showing one of the two the casting reservoirs recovered at Lamanai (LA 2790/4), down sprue and a bell-headed pin (LA 91/1) recovered with Burial N10-4/29.

Figure 4: Schéma d'un moule à la cire perdue montrant l'un des deux réservoirs de moulage retrouvés à Lamanai (LA 2790/4), down sprue et une épingle à tête campaniforme (LA 91/1) retrouvée dans la tombe N10-4/29.

(1994) having both Sn and As. The inclusions are $\mathrm{Pb}$ rich and copper sulfides are present. The trace level of $\mathrm{Ag}$ found has strong correlations with $\mathrm{Pb}$. This correlation should be explored further as it may indicate potential sourcing, or manufacturing connections.

Prills. These are small, spherical balls of copper which can form during either the smelting or casting process. Since copper ores are not locally available in Belize it is almost certain that melting and casting of already derived metallic copper, not smelting of copper ores, was occurring at the site (Bateson and Hall, 1977). During casting, droplets of molten copper may bounce away from open molds and cool while traveling through the air. This action causes the metal to form circular or roughly circular balls, which are termed prills; these very small metal objects typically fall to the ground and are found around the metal casting area. Alternatively, when performing a lost wax casting, if there is any wax remaining in the mold a violent reaction can occur, causing the molten metal to spurt out of the mold's pouring 


\begin{tabular}{|c|c|c|c|c|c|c|c|c|c|c|c|}
\hline Artifact No. & Reservoirs & Area sampled & $\mathrm{Cu}$ & Sn & As & $\mathrm{Fe}$ & $\mathrm{Ag}$ & $\mathrm{Pb}$ & S & $\mathrm{Se}$ & $\mathrm{Bi}$ \\
\hline \multirow[t]{10}{*}{ LA $2790-4$} & \multirow[t]{10}{*}{ large reservoir } & Body & 98.2 & 0.8 & 0.7 & 0.3 & & & & & \\
\hline & & Body & 98.6 & 0.5 & 0.6 & 0.2 & & & & & \\
\hline & & Body & 95.5 & 2.9 & 1.5 & 0.2 & & & & & \\
\hline & & Body & 98.6 & 0.3 & 0.5 & 0.3 & 0.3 & & & & \\
\hline & & Body & 98.6 & 0.4 & 0.5 & 0.2 & 0.3 & & & & \\
\hline & & Body & 96.7 & 1.6 & 1.4 & 0.3 & & & & & \\
\hline & & Avg body & 97.7 & 1.1 & 0.9 & 0.2 & 0.3 & & & & \\
\hline & & Inclusion & 86.8 & 0.5 & & 0.3 & 0.4 & & 9.8 & 2.2 & \\
\hline & & Inclusion & 88.7 & & & & & & 11.3 & & \\
\hline & & Inclusion & 43.6 & & & & 1.9 & 19.7 & & & 30.7 \\
\hline \multirow[t]{4}{*}{ LA $2790-1$} & \multirow[t]{4}{*}{ small reservoir } & Body & 99.5 & 0.3 & & 0.2 & & & & & \\
\hline & & Body & 99.2 & 0.3 & & 0.3 & & & & & \\
\hline & & Avg body & 99.3 & 0.3 & & 0.2 & & & & & \\
\hline & & Inclusion & 50.9 & 48.3 & & 0.5 & & & & & \\
\hline
\end{tabular}

Table 3: Chemical composition of the two casting reservoirs by SEM-EDS.

Tableau 3 : Composition chimique des deux réservoirs de moulage par SEM-EDS.

reservoir. This action will also cause prills to be formed and scattered around the casting area.

All eight prills found thus far at Lamanai have been recovered during MAP investigations in the area of Str. N11-18, located approximately $325 \mathrm{~m}$ north of the larger of the two Spanish churches. They range in size between approximately $2-5 \mathrm{~mm}$ in diameter; those that are larger in size were ideal for use as bell clappers. To our knowledge, the copper prills found at Lamanai are the first to be reported in the Maya area.

In order to investigate the metallurgy of prills the entire prill must be mounted and polished. Since this was deemed to be overly destructive to the artifacts only two of these small copper objects were selected for microstructural examination and chemical analysis. These particular kinds of artifacts are expected to have a specific microstructure based on their formation history. The microstructure should be a core dendritic structure with chill crystals at the surface and a relatively small grain structure (Figure 5). As expected, this exact feature was observed. Under crossed polars copper oxide inclusions were clearly visible due to the heavy amount of oxygenation prills receive during cooling and formation. Analysis of one of the supposed prills (LA 2081/2), however, revealed a completely different microstructure in which there was clear evidence of heavy cold working. The grains of this particular small, spherical object were found to be distorted with numerous working lines. In addition, a prominent fold indicative of a major reshaping of the metal was observed
(Figure 5). Initiation of corrosion is evident at the object's weakest point in this fold; cuprite and malachite intergrowth was observed in this area. Based on these lines of information what originally appeared to be a prill most likely represents a manufactured bell clapper. At this point in time it is not possible to determine whether this clapper was produced at Lamanai or arrived on site already in functional use inside a bell. In any case, both pebble and copper bell clappers have been identified at Lamanai, although pebble clappers are more commonly found in bells recovered in Terminal Postclassic-Spanish Colonial Period contexts (Simmons et al., 2009).

The chemical composition of both the prill as well as the bell clapper is indicative of metal recycling. The high traces of Sn (0.5 and 0.4), As (0.7 and 0.5), and $\mathrm{Ag}$ (0.1 and 0.2) for the prill and bell clapper, respectively, likely derive from the mixing of higher alloy artifacts (i.e. copper tin or copper arsenic alloyed artifacts) with more pure copper artifacts (Hosler, 2004; Shugar, 2008: 5). Similar compositional data were collected by Holser (2004: 212-213) for later period artifacts with traces of $\mathrm{Sn}$ (.04-2.59), As (0.16-1.2), and Ag (.06-0.25).

Blank. One copper artifact (LA 1149/1) recovered during MAP investigations of the Spanish Church Zone is a particularly unusual object given that none have ever been reported in the Maya area. This roughly rectangular-shaped block of solid copper weighing just slightly over 400 grams was recovered in the Spanish Church Zone. It was not found 


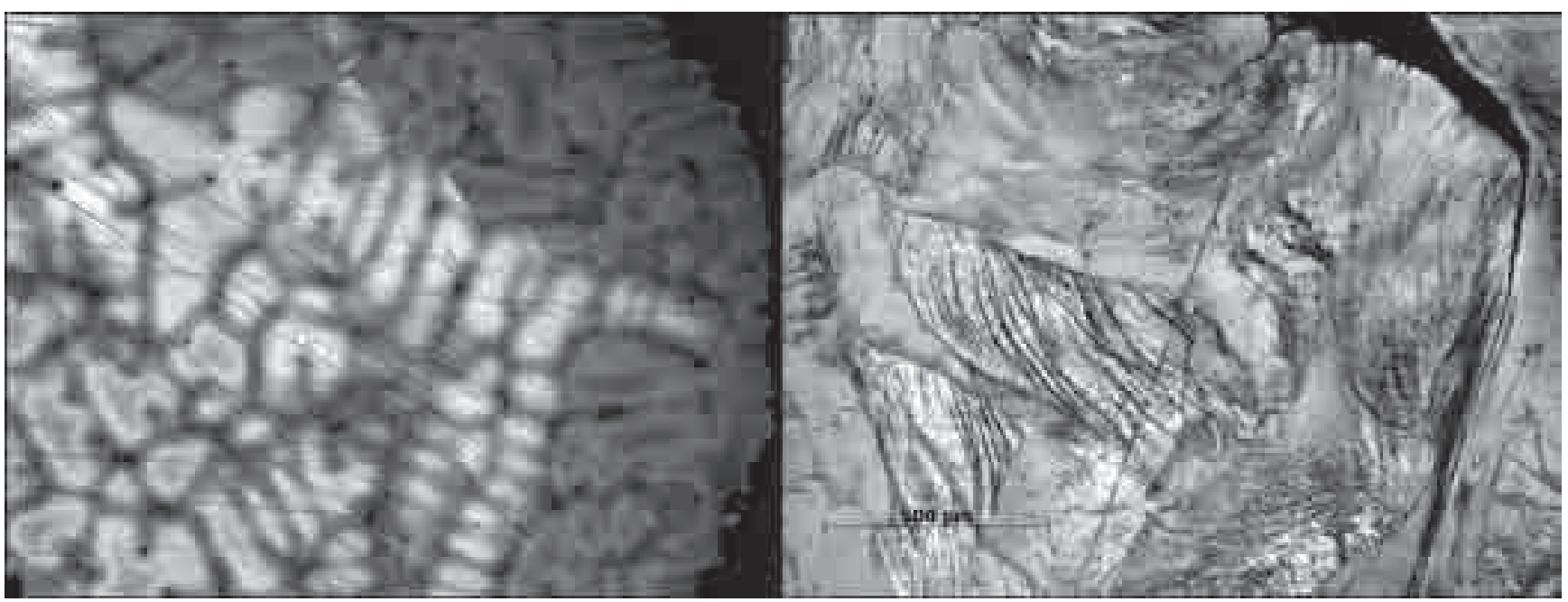

Figure 5: Microstructure of a copper prill and a bell clapper from Lamanai.

Figure 5 : Microstructure d'un prill de cuivre et d'un battant de cloche en provenance de Lamanai.

On the left is a normal prill (LA 2909/6) showing classic dendritic coring caused by fast cooling. On the right is the formed bell clapper (LA 2081/2) showing intense working with distorted slip lines, and a prominent fold in the metal to the right.

Sur la gauche se trouve un prill normal (LA 2909/6) exemplifiant le cas classique d'une solidification dendritique due à un refroidissement rapide. Sur la droite, le battant de cloche formé (LA 2081/2) montrant un travail intense avec des lignes d'imperfection déformées et un pli visible dans le métal vers la droite.

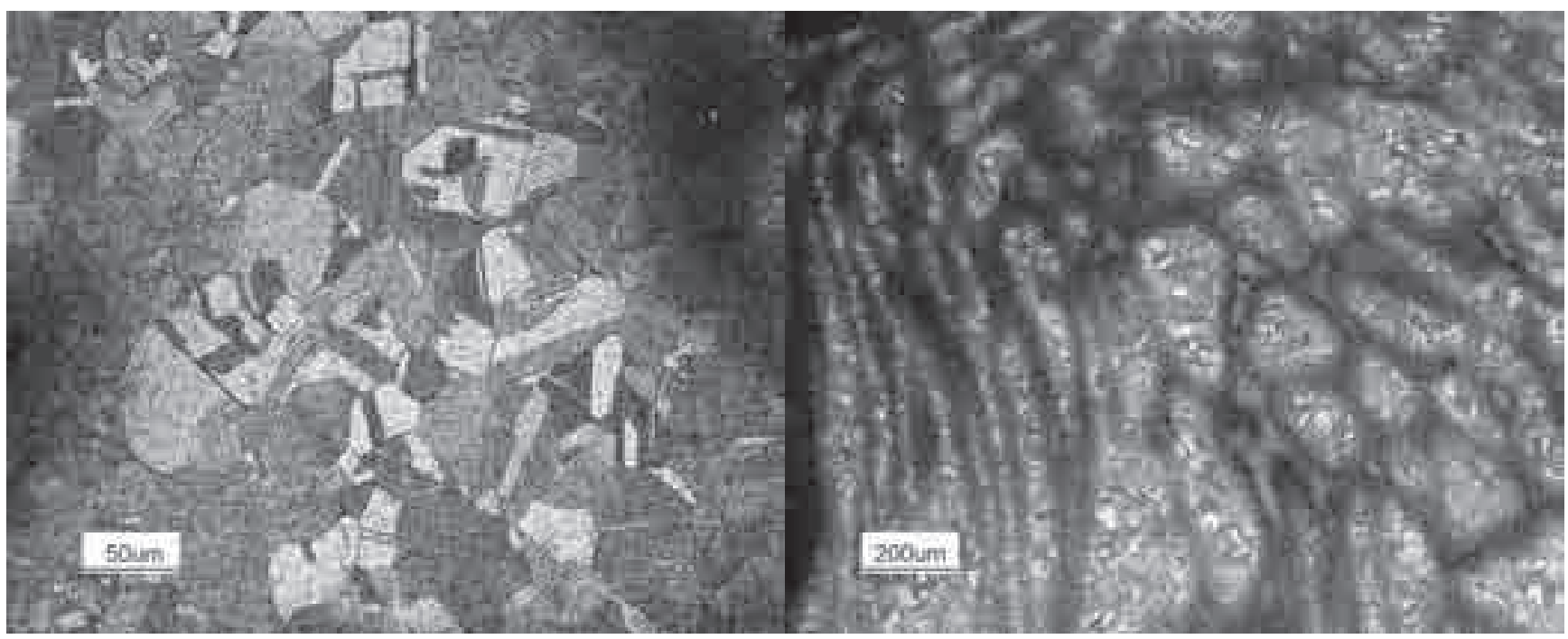

Figure 6: (See colour plate) Microstructure of copper blank LA 1149/1.

Figure 6: (Voir planche couleur) Microstructure d'un blank en cuivre LA 1149/1.

Image on the left shows irregular sized grains with annealing twins indicative of cold working and annealing. On the right the original dendritic coring is visible, viewed as darker lines that have been partially distorted by hammering. These darker lines are remnants of dendritic coring from the as cast state.

L'image sur la gauche montre un grain irrégulier avec annealing twins indicatifs de travail à froid et de recuit. Sur la droite, la solidification dendritique originelle est visible sous la forme de lignes plus sombres, partiellement détruites par martèlement. Ces lignes plus sombres représentent les restes de la solidification dendritique qui s'est produite lors du moulage. 


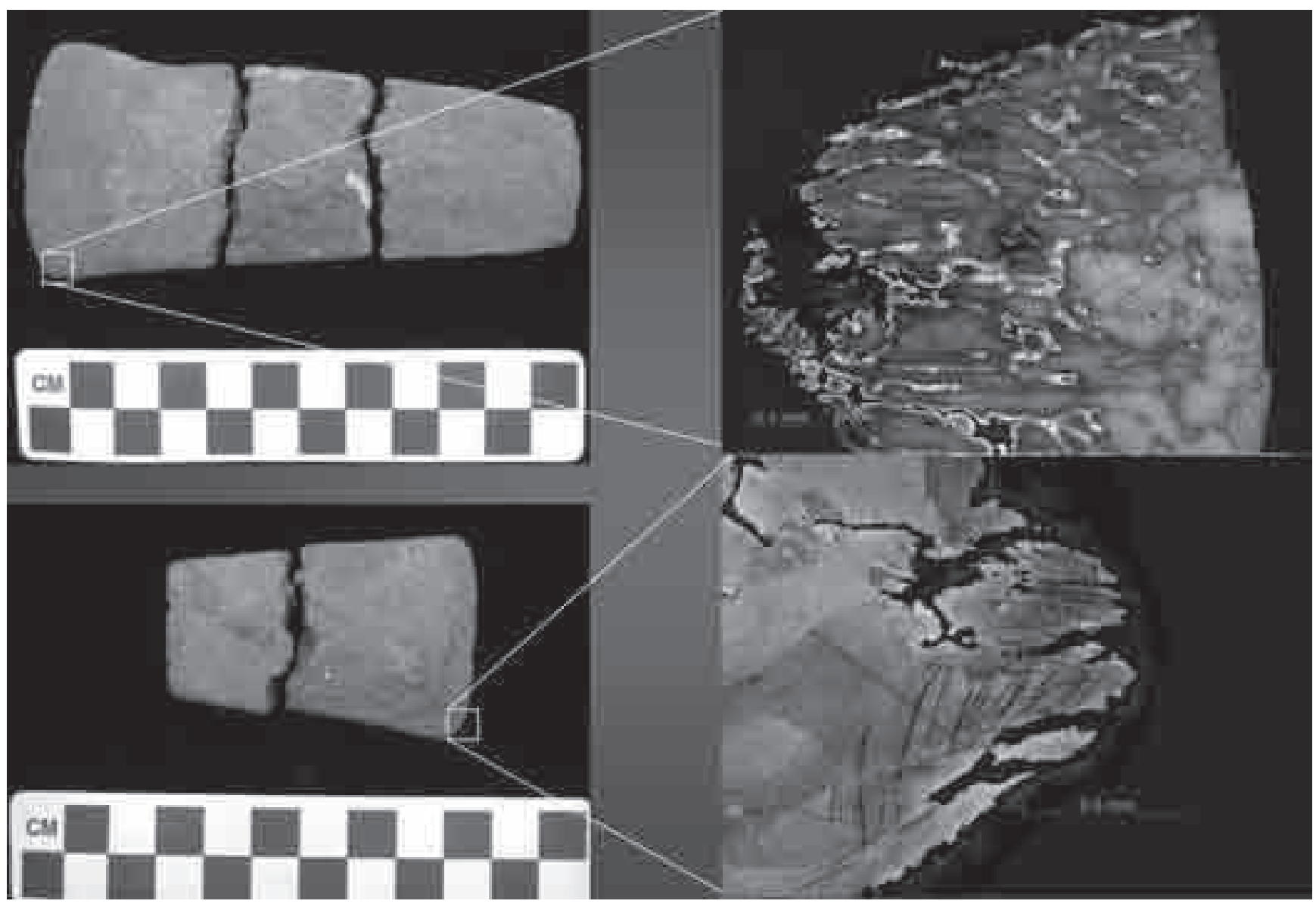

Figure 7: (See colour plate) Blade of top axe (LA 2790/5) and blade of bottom axe (LA 2790/6) showing minimal annealing and heavy working lines near the blade tips. LA 2790/6 shows signs of partial recrystallization, possibly due to under annealing or hot working. Figure 7: (Voir planche couleur) Lame d'une hache sommet (LA 2790/5) et lame d'une hache bas (LA 2790/6) montrant un recuit minime et des lignes de travail marquées à proximité des pointes de la lame. LA 2790/6 indique des signes de recristallisation partielle, potentiellement due soit au recuit trop limité soit à un travail à chaud.

with any other copper artifacts and was not associated with any structure, although it was found close to the edge of the New River Lagoon. It is possible that this object represents an ingot, yet it differs in shape from the other four possible copper ingots (or pouring reservoirs) that have been found at Lamanai (see Hosler, 1994: Figure 7.9), which are all round in shape. Although it would have also provided a substantial amount of raw material for lost-wax casting it is more likely that this artifact represents a blank from which larger copper objects could have been made (see below).

Metallographic examinations revealed a partially hammered as-cast structure that had been partially annealed (Figure 6). The original dendritic coring is seen as darker lines that have been partially distorted by hammering. The presence of annealing twins indicates that the object was cold worked and annealed but the varied size of the grains (not completely equiaxed) shows that the object has been only partially worked. This is what would be expected of a partially worked ingot or blank. It would have been cast, and if too much metal was poured, or it were not cast cleanly, it would have to be heavily worked into final shape. For some unknown reason this piece was never worked into a final shape.

In terms of its chemical composition the blank has no clear alloying visible. Although there are Sn levels at $0.34 \%$ and As levels at $0.36 \%$, these values, as seen with the other artifacts discussed here, are not considered high enough to indicate intentional alloying. The blank was most likely formed from remelted metal objects that had varying amounts of alloying, which is consistent with recycling of metals 
suggested by Hosler (2004) and Shugar (2005: 9). Given its size and general overall form it seems very likely that this object was destined to be worked into some kind of tool, such as an axe, chisel, or other woodworking tool of the kind that have been found previously at Lamanai. To our knowledge no such blanks had been found before in the Maya area.

\section{Finished Copper Objects}

Axes. Twenty-three axes and axe fragments have been found thus far at Lamanai (Simmons et al., 2009: 60). Based on the limited ethnohistorical and archaeological information currently available it appears that axes were produced by pouring molten metal into an open-shaped axe mold. The 16th century Florentine Codex shows a Mesoamerican metalsmith casting a metal axe into an opencast mold (Sahagún, 1959: Folio 796). These castings or blanks needed to be heavily worked to achieve their final form. In many cases, such blanks have lips which form when the poured metal extends over the edges of the mold. These lips can be hammered back or filed to achieve the final axe shape.

The process of hammering and sharpening the bit edge of the blade increases the hardness of the metal but at the same time decreases the metal's malleability (Rothenberg et al., 1978). It would therefore be important for the metalsmith to occasionally anneal the object and re-crystallize the metal, which would restore its plasticity and decrease its hardness or brittleness. This process would leave a microstructure with small equiaxed grains, annealing twins, and if hammered into final shape, distorted twins and working lines (Shugar, 2008: 9).

Examination of the microstructure of one recently recovered axe blade revealed a homogenous large grain structure with evidence of high porosity and heavy working near the tip of the blade (Figure 7). In addition, there was evidence for partial recrystallization of the metal. This may be due to either the axe being only partially annealed at lower than sufficient temperatures to allow for full recrystallization or the axe may have been partially hot worked. The poll (butt or back portion) of this axe shows some minimal working and light annealing at the surface, which would indicate only partial final shaping occurred to complete this axe.

Analyses of another recently recovered axe blade revealed similar minimal working of the blade without repeated annealing and working. Heavy working lines near the tip may be from use or exclusively from final shaping (Figure 7). Close macroscopic examination of the poll section of one of the longer axes recently recovered during MAP excavations revealed additional information on Maya metalworking

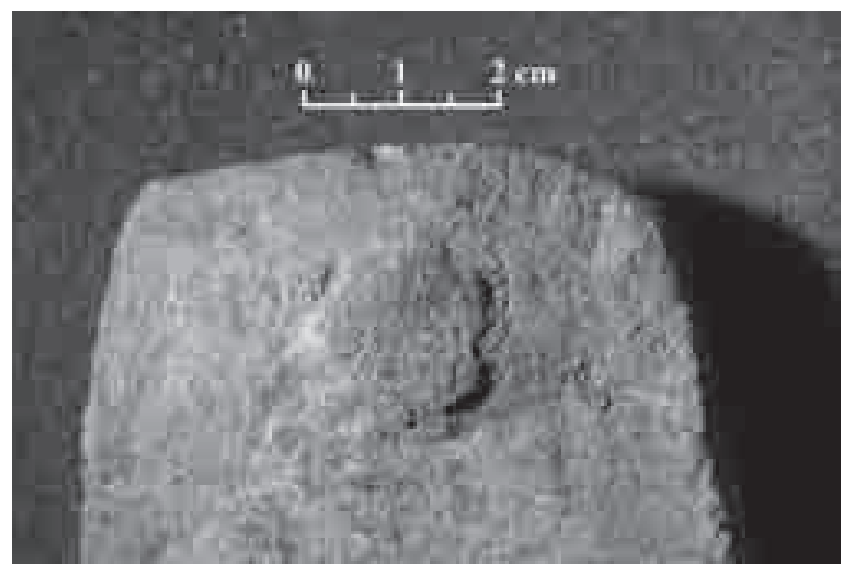

Figure 8: (See colour plate) Pole of axe LA 2790/3 showing the remnants of a down sprue after cleaning.

Figure 8: (Voir planche couleur) Manche de hache (LA 2790/3) présentant des marques du tube de coulées après nettoyage.

Photo courtesy of Dan Kushel.

Photographies publiées avec l'autorisation de Dan Kushel.

technology at Lamanai. Removal of some of the corrosion from the surface of this artifact revealed a roughly roundshaped, raised area located very close to the poll or haft end of the axe (Figure 8).

Although no casting molds have yet been found at Lamanai the presence of this particular production feature provides compelling evidence that some copper objects were most likely made in a bivalve or lost-wax mold rather than being open cast. In this case, a wax mold was likely formed around a blank, then coated in clay and eventually heated to remove the wax so that molten copper could fill the resulting void. Removal of the down sprue would leave a small protrusion on the surface of the axe similar to the one seen in Figure 8. If this interpretation is correct it would represent the first recorded occurrence of Maya copper axes being made in bivalve molds (Shugar, 2008: 12).

The chemical composition of the axes investigated as part of this study reveals two separate production process (Table 4). The axe fragment LA 2790/5 (Figure 7) has a complex copper alloy of tin (1.5\%) and arsenic (1.4\%) as does axe fragment LA $1153 / 1$ with $1.2 \%$ Sn and $1.0 \%$ As. Even though the alloy composition appears significant, these levels are almost certainly related to re-melting of higher alloyed metals (discussed by Hosler [1994]). As suggested by microstructural examination, this alloy composition would benefit the functionality of the axe by increasing the hardness of the metal, allowing for a sharper edge with greater longevity. 


\begin{tabular}{|c|c|c|c|c|c|c|c|c|c|c|c|}
\hline Artifact Number & Axe description & Area sampled & $\mathrm{Cu}$ & Sn & As & $\mathrm{Fe}$ & $\mathrm{Ag}$ & $\mathrm{Pb}$ & S & $\mathrm{Se}$ & $\mathrm{Ni}$ \\
\hline \multirow[t]{5}{*}{ LA 1149-1 } & \multirow{5}{*}{$\begin{array}{c}\text { Ingot or axe/chisel } \\
\text { blank }\end{array}$} & Body & 96.5 & 1.0 & 1.3 & 0.3 & 0.5 & & & & 0.4 \\
\hline & & Body & 97.7 & 0.6 & 0.7 & 0.4 & 0.4 & & & & 0.2 \\
\hline & & Avg body & 97.1 & 0.8 & 1.0 & 0.4 & 0.4 & & & & 0.3 \\
\hline & & Inclusion & 86.5 & 1.3 & & 0.4 & & 11.8 & & & \\
\hline & & Inclusion & 91.6 & 0.6 & & 0.4 & 0.6 & & 6.8 & & \\
\hline \multirow[t]{4}{*}{ LA $2790-5$} & \multirow{4}{*}{$\begin{array}{l}\text { Blade section of } \\
\text { long axe }\end{array}$} & Body & 95.7 & 1.7 & 1.7 & 0.4 & 0.6 & & & & \\
\hline & & Body & 96.4 & 1.4 & 1.2 & 0.3 & 0.6 & & & & \\
\hline & & Avg body & 96.0 & 1.5 & 1.4 & 0.3 & 0.6 & & & & \\
\hline & & Inclusion & 70.4 & & 0.4 & 0.4 & 17.5 & 5.4 & & 5.8 & \\
\hline \multirow[t]{5}{*}{ LA $2790-7$} & \multirow{5}{*}{$\begin{array}{l}\text { Back section short } \\
\quad \text { axe }\end{array}$} & Body & 98.5 & 0.3 & 0.6 & 0.2 & 0.5 & & & & \\
\hline & & Body & 98.1 & 0.3 & 0.9 & 0.3 & 0.4 & & & & \\
\hline & & Avg body & 98.3 & 0.3 & 0.8 & 0.3 & 0.4 & & & & \\
\hline & & Inclusion & 50.2 & & & & & 49.8 & & & \\
\hline & & Inclusion & 87.7 & & & & & & 9.2 & 3.1 & \\
\hline \multirow[t]{4}{*}{ LA $2791-1$} & \multirow[t]{4}{*}{ Axe fragment } & Body & 98.0 & & 1.2 & 0.3 & 0.5 & & & & \\
\hline & & Body & 98.7 & & 0.6 & 0.3 & 0.4 & & & & \\
\hline & & Avg body & 98.3 & & 0.9 & 0.3 & 0.5 & & & & \\
\hline & & Inclusion & 51.6 & 0.3 & & 0.5 & & 47.6 & & & \\
\hline \multirow[t]{4}{*}{ LA 1153-1 } & \multirow[t]{4}{*}{ Axe fragment } & Body & 96.7 & 1.6 & 1.1 & 0.2 & 0.3 & & & & \\
\hline & & Body & 97.6 & 1.1 & 1.0 & 0.3 & 0.2 & & & & \\
\hline & & Body & 97.5 & 1.0 & 0.8 & 0.3 & 0.3 & & & & \\
\hline & & Avg body & 97.2 & 1.2 & 1.0 & 0.3 & 0.3 & & & & \\
\hline
\end{tabular}

Table 4: Chemical composition for several axes by SEM-EDS. Two main groups are present-one with relatively pure copper and the other with low alloys of $\mathrm{Sn}$ and As.

Tableau 4: Composition chimique de diverses haches par SEM-EDS. L'on peut distinguer deux groupes : le premier avec du cuivre relativement pur et le second avec des alliages de Sn et As.

In contrast, some of the axe fragments from late deposits at Lamanai, including LA 2790/7 and LA 2791/1, have very pure copper compositions with little alloying. The slightly higher lever of arsenic (0.8\%) in axe LA 2790/7 likely resulted from the co-melting of pure copper objects with alloyed arsenic-rich copper objects, some of which may have been imported to the site as early as Early Postclassic times. This closely matches observed characteristics of other copper artifacts from Lamanai (Shugar, 2005, 2008).

Bells. More bells have been recovered at Lamanai than any other type of metal artifact (Simmons et al., 2009: 60). Over $42 \%$ of the entire assemblage of copper-base artifacts from Lamanai consists of bells, most of which are plain walled and either pyriform or globular in shape (Figure 3). A total of 23 of the 79 (29\%) total bells recovered thus far from Lamanai have been analysed to date (Hosler, 1994; Hosler and MacFarlane, 1996; Shugar, 2005, 2008; Williams, 1990). The results of this research reveal that while bell formation technology remained the same over the centuries there were changes in the chemical compositions of Lamanai's bells that occurred over the course of the Postclassic Period.

The results of LOM analyses revealed that all bells exhibited a similar large-grained microstructure that is typical of slow cooling of molten metal. This strongly suggests that the bells from Lamanai were made using the lost-wax casting technique. The remnant down sprues on bell suspension loops, which are a common feature of lost-wax cast bells in Mesoamerica, provide further evidence for lost-wax casting as the method of production for Lamanai's bells. The slow cooled microstructure is probably due to the clay mold used for casting acting as an insulating material, which effectively slowed the cooling process. The thin walled bells produced by the Maya would require this since cooling in open air would likely produce a smaller, coarser overall grain structure.

The chemistry of the bells varies as might be expected from objects of unknown origins (Table 5). The bells 
analysed for this study may be broken down into three types: first is a copper arsenic alloy with between 0.8 and $2.2 \mathrm{wt} \%$. This composition is very clean with traces of $\mathrm{Sn}$, $\mathrm{Fe}$ and Ag. This level of As suggests intentional alloying, and although there are discussions as to the limit of As concentration that would signify this intention, a value of $1 \%$ is commonly considered the lower limit (Budd, 1992; Charles, 1967; Eaton and McKerrell, 1977; Northover, 1989; Zwicker, 1991). In fact, several of these artifacts are so similar in terms of the chemistries that they could be from the same ore source. The second type is a relatively "clean" copper with traces of Sn, and Fe with no As. The inclusions are $\mathrm{Pb}$ rich. The third type appears to be more of a mixture of a more pure composition similar to the second type and a more complex alloyed composition similar to the first type (Table 5). The inclusions in this type are coppers sulphides.

Needles and Fish Hook. To date 10 needles, 5 fishhooks, 2 pins, 2 pin heads, 2 pin tips, and 2 bell-headed pins have been found at Lamanai (Simmons et al., 2009). These utilitarian artifacts are made by hammering pieces of metal into longer shapes with rounded points. The process can require some extensive work, leaving signature microstructures of heavy working and flow in one direction, very small equiaxed grains, heavy distortion to annealing twins as well as widespread working lines. These artifacts could also be produced in another way that has not yet been explored.

The lost-wax casting process entails removal of the object from the down sprue. The remaining down sprue and casting reservoir could later be recycled and melted to produce other objects. But if the down sprues were detached from both the object and the casting reservoir they could serve as excellent blanks for producing pointed objects of various types, including needles, fish hooks and pins (see Figure 4). Several eye loop types for needles have been recorded and these include a tucked type loop, a flap type loop and a punched type loop (also see Hosler, 1994). Close examination of the eye loops of needles recently recovered during MAP investigations at Lamanai revealed two of these types -the flap type and the punch type (see Shugar 2008: Figure 19). Two needles (LA 1580/18, and LA 1581/25) and a fish hook (LA 1575/2) that are illustrative of this kind of metalworking technology are reported on here.

The microstructures of the two needles and the fish hook show extensive working and annealing. The tip of one of the needles (LA 1581/25) shows small equiaxed grains with heavily distorted annealing twins and many working lines, indicating the needle point was left in a final worked state. The microstructure of the eye loop of LA 1580/18 shows

\begin{tabular}{|c|c|c|c|c|c|c|c|c|c|c|c|}
\hline Artifact No. & Bell Type & Area sampled & $\mathrm{Cu}$ & Sn & As & $\mathrm{Fe}$ & $\mathrm{Ag}$ & $\mathrm{Pb}$ & $S$ & $\mathrm{Se}$ & $\mathrm{Ni}$ \\
\hline \multirow[t]{4}{*}{ LA $1238-1$} & \multirow[t]{4}{*}{ pyriform } & Body & 98.9 & 0.5 & & 0.3 & & & & & \\
\hline & & Body & 98.7 & 0.5 & & 0.4 & & & & & \\
\hline & & Avg Body & 98.8 & 0.5 & & 0.4 & & & & & \\
\hline & & Inclusion & 88.5 & 0.6 & & 0.4 & & 10.3 & & & 0.1 \\
\hline \multirow[t]{4}{*}{ LA $1240-1$} & \multirow[t]{4}{*}{ pyriform } & Body & 96.7 & 0.1 & 1.9 & 0.3 & & & & & \\
\hline & & Body & 95.4 & 0.2 & 2.9 & 0.4 & & & & & \\
\hline & & Body & 96.9 & 0.2 & 1.9 & 0.3 & & & & & \\
\hline & & Avg Body & 96.3 & 0.2 & 2.2 & 0.4 & & & & & \\
\hline \multirow[t]{5}{*}{ LA $1243-1$} & \multirow[t]{5}{*}{ pyriform } & Body & 97.7 & 1.0 & 0.9 & 0.3 & & & & & \\
\hline & & Body & 98.1 & 0.6 & 0.7 & 0.4 & & & 0.03 & & \\
\hline & & Body & 98.7 & 0.8 & & 0.3 & & & & & \\
\hline & & Avg Body & 98.2 & 0.8 & 0.8 & 0.3 & & & 0.03 & & \\
\hline & & Inclusion & 82.9 & 0.6 & & 1.3 & & & 11.6 & 2.7 & \\
\hline \multirow[t]{5}{*}{ LA 1244-1 } & \multirow[t]{5}{*}{ fragment } & Body & 97.6 & 0.2 & 1.4 & 0.5 & 0.1 & & & & \\
\hline & & Body & 97.3 & 0.2 & 1.8 & 0.3 & 0.2 & & & & \\
\hline & & Body & 97.2 & 0.5 & 1.2 & 0.4 & 0.3 & & & & \\
\hline & & Avg Body & 97.3 & 0.3 & 1.5 & 0.4 & 0.2 & & & & \\
\hline & & Inclusion & 84.9 & 0.5 & & 1.0 & & & 9.4 & 3.9 & \\
\hline
\end{tabular}

Table 5: Chemical composition of bells analyzed by SEM-EDS.

Tableau 5: Composition chimique de cloches analysées par SEM-EDS. 


\begin{tabular}{|c|c|c|c|c|c|c|c|c|c|c|c|}
\hline Artifact Numbers & Artifact types & Area sampled & $\mathrm{Cu}$ & Sn & As & $\mathrm{Fe}$ & $\mathrm{Ag}$ & $\mathrm{Pb}$ & $S$ & $\mathrm{Bi}$ & Se \\
\hline \multirow[t]{5}{*}{ LA $1580-18$} & \multirow[t]{5}{*}{ needle fragment } & Body & 98.0 & 0.5 & 0.5 & 0.3 & 0.7 & & & & \\
\hline & & Body & 99.0 & 0.3 & & 0.3 & 0.4 & & & & \\
\hline & & Avg Body & 98.5 & 0.4 & 0.5 & 0.3 & 0.6 & & & & \\
\hline & & Inclusion & 66.9 & & & 0.4 & 0.5 & 18.5 & & 13.7 & \\
\hline & & Inclusion & 83.1 & 16.3 & & 0.4 & 0.2 & & & & \\
\hline \multirow[t]{4}{*}{ LA $1581-25$} & \multirow[t]{4}{*}{ needle } & Body & 97.9 & 0.4 & 0.8 & 0.2 & 0.5 & & & & \\
\hline & & Body & 98.6 & 0.3 & 0.5 & 0.3 & 0.3 & & & & \\
\hline & & Avg Body & 98.2 & 0.3 & 0.6 & 0.2 & 0.4 & & & & \\
\hline & & Inclusion & 35.3 & & & 0.3 & 0.6 & 51.5 & & 12.2 & \\
\hline \multirow[t]{4}{*}{ LA $1575-2$} & \multirow[t]{4}{*}{ fish hook } & $1575-2$ & 96.9 & 0.7 & 1.7 & 0.3 & 0.4 & & & & \\
\hline & & $1575-2$ & 97.1 & 0.4 & 1.9 & 0.4 & 0.3 & & & & \\
\hline & & Avg Body & 97.0 & 0.6 & 1.8 & 0.4 & 0.3 & & & & \\
\hline & & $1575-2$ inc & 85.5 & & & 0.6 & & & 6.5 & & 6.7 \\
\hline
\end{tabular}

Table 6. Chemical composition of needles and fish hook by SEM-EDS.

Tableau 6. Composition chimique d'aiguilles et hameçons analysées par SEM-EDS.

fine equiaxed grains with extensive annealing twins but no evidence of final working. This suggests that the eye loop was made prior to forming the fine point. To achieve a pointed shape the needle tip was hammered and worked. The process of repeatedly working and annealing the tip would ultimately anneal the eye loop, as was observed in the microstructures of these needles.

The chemical composition of the needles falls into two groups (Table 6). One of these is a copper arsenic alloy. The fishhook (LA 1575/2) has 1.8\% As, which is rather high in comparison to other utilitarian objects recently found. There are traces of $\mathrm{Sn}, \mathrm{Ag}$, and Fe but there is no indication that this composition represents recycling of metals to produce this artifact. The second group includes pointed objects of relatively "clean" copper with approximately $0.4 \%$ Sn, $0.5 \%$ As and $0.5 \% \mathrm{Ag}$. This composition is consistent with a recycling of metals with higher concentrations of $\mathrm{Sn}$ and As.

\section{Conclusions}

The bells, rings and other status display objects imported into Lamanai during the first centuries of the Postclassic were made of a very "pure" copper (Hosler, 1994: 208). It was not until Late Postclassic times that the first solid evidence for Maya experimentation in copper metallurgy appears in the Maya area (Paris, 2008; Paris and Peraza Lope, 2013; Simmons and Shugar, 2013; Simmons et al., 2009; Urban et al., 2013; Weeks, 2013). Although bells and other status display/ritual items were part of this later assemblage at Lamanai, a number of utilitarian copper objects, including axes, needles and fish hooks, were evidently being produced on-site at this time. The results of emission spectroscopy analyses strongly suggest that the anomalous chemistries of a number of copper artifacts at Lamanai can be attributed to recycling behavior wherein copper objects were melted and re-cast into new forms (Hosler, 1994; Shugar, 2005, 2008; Williams, 1990). Metal recycling behavior has also been documented in the Northern Maya Lowlands, specifically at the site of Mayapán, Yucatán (Paris, 2008, 2013). It is possible that the comparatively small number of copper objects from Cib Phase ceramic deposits reflects later Maya recycling behavior (Simmons et al., 2009: 70). When reviewing the combined data in Table 2, it appears that the variation in chemical compositions within this group of artifacts is somewhat limited, with small overall ranges in the amounts of tin, arsenic, iron and silver. This may well represent a collection of metals that has undergone repeated episodes of remelting and recycling. Over time, repeated remelting would effectively meld compositions of different metals together and reduce the concentration of the more oxidizing elements, As in particular.

One of the strongest lines of evidence supporting the idea that copper metallurgy in the Southern Lowlands was a Maya technological innovation that had its roots in the precolumbian past comes from the objects themselves -all are of typical Mesoamerican design, form and production technology. The predominant technology used to create 
the copper-base objects found archaeologically in the Maya Lowlands was lost-wax casting. The elaborate clothing ornaments, bells and rings associated with Early Postclassic elite burials were all produced using the lost-wax casting technology. The recovery of two casting reservoirs at Lamanai dating to Spanish Colonial times indicates that Maya metalsmiths adopted a long-standing technological tradition developed centuries earlier in West Mexico. The sizes and shapes of these casting reservoirs provide direct information on such specific physical aspects of lost-wax cast molds as their forms and dimensions, which is a first from the Maya Lowland area.

A notable point regarding the copper assemblage at Lamanai is the almost complete absence of metal objects of European design. Despite Lamanai's status as an important mission community, Spanish metal items such as crucifixes, copper-alloy stars, devotional medals, rings, stamps and seals are absent (Simmons et al., 2009: 68). While these artifacts are commonly found at Spanish Colonial Period sites in Florida and throughout the Caribbean (Deagan, 2002) only one of the 187 copper objects recovered at Lamanai thus far may be of European origin. In summary, the absence of copper objects of European design, the intermittent nature of Spanish activity in the region, utilization of traditional precolumbian manufacturing technologies, and the overall small quantity of metal at the site suggest that metallurgy at Lamanai was a wholly Maya technological endeavour, not one that was introduced by the Spanish.

The results of research conducted in the late 1980's and early 1990's by Dorothy Hosler (1994; Hosler and MacFarlane, 1996) and more recently (Shugar, 2005, 2008) have provided valuable insights into the nature of Maya metallurgy during Postclassic and Spanish colonial times. The presence of several previously unknown copper artifact types at the site along with the results of recent chemical compositional and microstructural analysis greatly strengthen the argument for localized re-melting and casting of copper-base artifacts in the Maya Lowlands. The copper prills, casting reservoirs and probable tool blank found during recent MAP investigations at Lamanai are the first to be reported in the Southern Maya Lowland area. The presence of the prills and casting reservoirs affirms that lost-wax casting was a key part of the technological repertoire of Maya metalsmiths. Rectangular-shaped copper blanks that were likely destined for cold working into tools such as axes or chisels also appear to have been part of late Maya metallurgical technology in the Southern Lowlands.

Future investigations at Lamanai will be aimed at identifying additional specific evidence for localized production of copper objects. For instance, the area in which the prills were recently located will be investigated more thoroughly for additional evidence of on-site production. Specific artifact types indicative of localized production would include casting debris, such as more prills, solidified spills of molten metal, mould fragments and ceramic crucibles. Handheld XRF may be used on site to help identify areas which may have higher concentrations of copper. Such concentrations may indicate the presence of copper production workshops, perhaps with furnaces for melting of metal, none of which have been positively identified in the Maya Lowland area to date. Such a discovery would add immeasurably to our understanding of the nature of ancient Maya metallurgical technology.

\section{Acknowledgements}

Our sincere thanks to the Belize Institute of Archaeology staff, especially Drs Jaime Awe and John Morris. We are very grateful to Dr Dorothy Hosler of MIT for her analyses of copper artifacts recovered by Dr David Pendergast. Dr Bruce Kaiser has provided much support in XRF analyses. We are very grateful to Roxanne Dehenain, Hélène Rey and Eric Tessier for the French translations of the abstract as well as the Figure and table captions. Our very special thanks go to Drs Elizabeth Graham and David Pendergast for all their support over the years. Financial support has been provided by research grants from the H. John Heinz III Fund for Latin American Archaeology and a Charles L. Cahill award from the University of North Carolina Wilmington.

\section{References}

Aimers, J., 2007. The Curse of the Ware: Using Ceramic Systems in Belize. Research Reports in Belizean Archaeology 4: 101110.

Aimers, .J, 2013. (editor). Ancient Maya Pottery: Classification, Analysis and Interpretation. Gainesville, University Press of Florida.

Bateson, J.H. and Hall, I.H.S., 1977. The Geology of the Maya Mountains, Belize. Her Majesty's Stationary Office, London.

Budd, P., 1992. Alloying and Metalworking in the Copper Age of Central Europe. Bulletin of the Metals Museum, Vol. 17: 3-14.

Charles, J.A., 1967. Early Arsenical Bronzes - A Metallurgical View. American Journal of Archaeology, Vol. 71: 21-26.

Eaton, R. and McKerrell H., 1977. Near Eastern alloying and some textual evidence for the early use of arsenical copper. World Archaeology, Vol. 8 (2): 168-191.

Graham, E., 1987. Terminal Classic to Early Historic Period Vessel Forms from Belize. In P. Rice and R. Sharer (eds). 
Maya Ceramics. BAR International Series, 345(i). British Archaeological Reports, Oxford, England: 73-98.

Hosler, D., 1986. The Origins, Technology, and Social Construction of Ancient West Mexican Metallurgy. Ph.D. dissertation, University of California, Santa Barbara.

Hosler, D., 1994. The Sounds and Colors of Power: The Sacred Metallurgy of Ancient West Mexico. MIT Press, Cambridge, Massachusetts.

Hosler, D., 1995. Sound, Color and Meaning in the Metallurgy of Ancient West Mexico. World Archaeology, 27: 100-115.

Hosler, D., 2001. Metal: Tools, Techniques and Products. In S. Evans and D. Webster (eds). Archaeology of Ancient Mexico and Central America: An Encyclopedia. Garland Publishing, London: 454-457.

Hosler, D. and Macfarlane, A., 1996. Copper Sources, Metal Production, and Metals Trade in Late Postclassic Mesoamerica. Science, 273: 1819-1824.

Howie, L., 2007. Pottery Production and Exchange in the Aftermath of the Maya Collapse: A Technological Study of Postclassic to Spanish Colonial Ceramics at Lamanai, Belize. In S.E. Simmons and E. Graham (eds). Preliminary Report of the 2007 Field Season at Lamanai, Belize: The Lamanai Archaeological Project. Report submitted by the University of North Carolina Wilmington to the Belize Institute of Archaeology.

Long, S., 1964. Cire Perdue Copper Casting in Pre-Columbian Mexico: An Experimental Approach. American Antiquity, 30(2): 189-192.

Lothrop, S.K., 1952. Metals from the Cenote of Sacrifice, Chichen Itza, Yucatan. With sections by W.C. Root and T. Proskouriakoff. Peabody Museum of Archaeology and Ethnology, Cambridge.

Northover, J.P., 1989. Properties and Use of ArsenicCopper Alloys. In Old World Archaeometallurgy, edited by A. Hauptmann, E. Pernicka and G.A. Wagner, 111-117. Bochum: Der Anschnitt Beiheft 7.

Paris, E. H., 2008. Metallurgy, Mayapán, and the Postclassic Mesoamerican World System. Ancient Mesoamerica, 19: 43-66.

Paris, E.H. and Peraza Lope, C., 2013. Breaking the Mold: The Socioeconomic Significance of Metal Artifacts at Mayapán. In S.E. Simmons and A.N. Shugar (eds). Archaeometallurgy in Mesoamerica: Current Approaches and New Perspectives. University Press of Colorado, Boulder:161-202.

Pendergast, D. M., 1981. Lamanai, Belize: Summary of Excavation Results, 1974-1980. Journal of Field Archaeology, 8: 29-53.

Pendergast, D. M., 1986. Stability through Change: Lamanai, Belize, from the Ninth to the Seventeenth Century. In J.A. Sabloff and E. Wyllys Andrews, E.W, V (eds). Late
Lowland Maya Civilization: Classic to Postclassic. University of New Mexico Press, Albuquerque: 223-249.

Pendergast, D. M., 1991. The Southern Maya Lowlands Contact Experience: The View from Lamanai, Belize. In D. Thomas (ed). The Spanish Borderlands in Pan-American Perspective. Columbian Consequences, vol. 3. Smithsonian Institution Press, Washington, D.C.: 336-354.

Pendergast, D. M., 1993. Worlds in Collision: The Maya/ Spanish Encounter in Sixteenth and Seventeenth Century Belize. Proceedings of the British Academy, 81: 105-143.

Rothenberg, B., Tylecote, R. and Boydell, P., 1978. Chalcolithic Copper Smelting: Excavations and Experiments. Institute of Archaeo-Metallurgical Studies, London.

DE Sahagún, B., 1959. Florentine Codex: General History of the Things of New Spain, Book 9-The Merchants. Translated and edited by Charles E. Dibble and J.O. Anderson. School of American Research and University of Utah, Salt Lake City.

Shugar, A.N., 2005. Metallurgical Investigation of Metal Artifacts from Lamanai, Belize. In Preliminary Report of the 2005 Field Season at Lamanai, Belize: The Maya Archaeometallurgy Project. UNCW Anthropological Papers, 5. Papers of the Maya Archaeometallurgy Project, 3. Wilmington: University of North Carolina.

Shugar, A.N., 2008. Microstructural and Chemical Analyses of Copper Artifacts from Lamanai, Belize. In Preliminary Report of the 2008 Field Season at Lamanai, Belize: The Maya Archaeometallurgy Project. UNCW Anthropological Papers, 10. Papers of the Maya Archaeometallurgy Project, 5.

Shugar, A. N. and Scott E. S.E., n.d. Material Control and Political Economy: Archaeometallurgy at Lamanai, Belize. Manuscript on file at Buffalo State College, Buffalo.

Simmons, S.E., 1999. Archaeometallurgy Project, Lamanai, Belize, 1999. Report submitted to the H. John Heinz III Fund for Latin American Archaeology, Pittsburgh and on file at the Belize Institute of Archaeology, Belmopan.

Simmons, S.E., 2004. Preliminary Report of the 2004 Field Season at Lamanai, Belize: The Maya Archaeometallurgy Project. UNCW Anthropological Papers, 2. Papers of the Maya Archaeometallurgy Project, 2. Wilmington: University of North Carolina.

Simmons, S.E., 2005a. Preliminary Report of the 2005 Field Season at Lamanai, Belize: The Maya Archaeometallurgy Project. UNCW Anthropological Papers, 5. Papers of the Maya Archaeometallurgy Project, 3. Wilmington: University of North Carolina.

Simmons, S.E., 2005b. Investigations in the Church Zone: Maya Archaeometallurgy at Spanish Colonial Lamanai, Belize. Research Reports in Belizean Archaeology, 2: 231-239.

Simmons, S.E., 2006. Preliminary Report of the 2006 Field Season at Lamanai, Belize: The Maya Archaeometallurgy 
Project. UNCW Anthropological Papers, 7. Papers of the Maya Archaeometallurgy Project, 3. Wilmington: University of North Carolina.

Simmons, S.E., n.d. Distance and the Maintenance of Status in Postclassic Maya Society: Perspectives from Lamanai, Belize. In Discourses of Distance among the Maya, edited by Timothy Pugh and Cameron McNeil. University Press of Colorado. In press.

Simmons, S.E. and Howard, L.J., 2003. Preliminary Report of the 2001-2002 Field Seasons at Lamanai, Belize: The Maya Archaeometallurgy Project. UNCW Anthropological Papers 1, University of North Carolina Wilmington, North Carolina.

Simmons, S. E. and Shugar, A.N., 2013. Archaeometallurgy in Ancient Mesoamerica. In Archaeometallurgy in Mesoamerica: Current Approaches and New Perspectives, edited by A. Shugar and S.E. Simmons. University Press of Colorado, Boulder: $1-28$.

Simmons, S. E., Pendergast, D.M. and Graham, E., 2009. Maya Metals: The Context and Significance of Copper Artifacts in Postclassic and Early Historic Lamanai, Belize. Journal of Field Archaeology, 34(1): 57-75.
Smith, M. and Berdan, F., 2003. Postclassic Mesoamerica. In M. Smith and F. Berdan (eds). The Postclassic Mesoamerican World. Salt Lake City, University of Utah Press, 3-13.

Urban, P., Shugar, A., Richardson, L., and Schortman, E., 2013. The Production of Copper at El Coyote: Processing, Dating and Political Economy. In A.N. Shugar and S.E. Simmons (eds). Archaeometallurgy in Mesoamerica: Current Approaches and New Perspectives. University Press of Colorado, Boulder: 77-112.

Weeks, J., n.d. Late prehistoric K'iche' metal Working at Utatlan, Guatemala. In A.N. Shugar and S.E. Simmons (eds), 2013. Archaeometallurgy in Mesoamerica: Current Approaches and New Perspectives. University Press of Colorado, Boulder: 113134.

Williams, K., 1990. An Examination of Maya Metallurgy 11501540 AD. Unpublished B.S. thesis, Massachusetts Institute of Technology, Cambridge, Massachusetts.

Zwicker, U. 1991. Natural copper-arsenic alloys and smelted arsenic bronzes in early production. In Decouverte du Metal, edited by C. Eluere and J-P. Mohen, 331-340. Paris, Picard. 